\title{
Energetikai konvergencia az Energia 2020 stratégia tükrében
}

\section{A konvergenciaszámítások alkalmazásának egy alternatív lehetősége}

\begin{abstract}
Az Európai Unió a közös fellépést hangsúlyozva az Energia 2020 elnevezésü dokumentumban az energiahatékonyságra, a megújuló energiaforrások részarányára és az üvegházhatású gázok kibocsátására vonatkozóan három célt tűzött ki. Tanulmányunkban a 28 tagállam elörehaladását vizsgáljuk a vállalások tükrében 2001 és 2012 között. A $\sigma$ - és a $\beta$-konvergencia számításával igazoljuk a tagállamok közötti összetartást, ugyanakkor a $\gamma$-konvergencia eredményei árnyalják a képet: a hiányából arra következtethetünk, hogy az egyes tagállamok közötti különbségek ugyan megmaradtak 2001 és 2012 között, mértékük azonban jelentősen csökkent. A felzárkózás üteme a megújuló energiaforrások esetében a leggyorsabb, az energia- és emisszióintenzitásnál a kedvező folyamatokat negatívan befolyásolja a 2008-2009-es válság, átmeneti divergenciát okozva. Az úgynevezett konvergenciaklubok számítása során kialakult csoportok a régi és új tagországok közötti különbségekre hívják fel a figyelmet. ${ }^{*}$

Journal of Economic Literature (JEL) kód: P28, P48, Q48.
\end{abstract}

\section{Bevezetés}

Az Európai Unió és tagállamai komoly energetikai kihívások előtt állnak: többek között erősödik az importfüggőség, az eddig elért diverzifikáció fokozása korlátokba ütközik, az energiaárak nagymértékben ingadoznak, az energiapiacok átláthatósága is korlátozott. A közösség intézményei az elmúlt évek során számos energiastratégiai dokumentumot fogadtak el és ültettek át a gyakorlatba. Ezek célja, hogy egységes keretet biztosítsanak a meglévő problémák megoldásának, támogassák a tagállamokat a jövőbeli kihívásokra való felkészülésben, hosszú távon elősegítsék az egységes

* A tanulmány a TÁMOP-4.2.1.B10/2/KONV-2010-0001. projekt részeként - az Új Magyarország Fejlesztési Terv keretében - az Európai Unió támogatásával, az Európai Szociális Alap társfinanszírozásával valósult meg.

Sebestyénné Szép Tekla egyetemi tanársegéd, Miskolci Egyetem Gazdaságtudományi Kar Világ- és

Regionális Gazdaságtan Intézet (e-mail: regtekla@uni-miskolc.hu).

A kézirat első változata 2015. március 11-én érkezett szerkesztőségünkbe.

DOI: http://dx.doi.org/10.18414/KSZ.2016.5.564 
energiapiac kialakítását. Az 1. táblázat bemutatja, hogyan alakították ki, pontosították az úgynevezett 20-20-20-as célokat (2020-ra a megújuló energiafelhasználás részarányának 20 százalékra növelése, az üvegházhatású gázok kibocsátásának 20 százalékos csökkentése, valamint az energiahatékonyság 20 százalékos növelése).

\section{1. táblázat}

A 20-20-20-as európai energiapolitikai célok fontosabb mérföldkövei

Dokumentum
Energy for the future: renewable
sources of energy ( $E C[1997])$
Az energiahatékonyságról, avagy
többet kevesebbel (EB [2005])
Energiahatékonysági cselekvési
terv ( $E B[2006 b])$

Európai stratégia az energiaellátás fenntarthatóságáért, versenyképességéért és biztonságáért (EB [2006a])

Európai energiapolitika $(E B[2007 b])$

Teljesítőképesség/célkitűzés

Céldátum

A megújuló energia 12 százalékos részaránya

2010

a végső felhasználásban.

20 százalékos energiahatékonysági

teljesítőképesség.

20 százalékos energiahatékonysági

teljesítőképesség.

A megújuló energia 21 százalékos

részarányának megvalósítása

az elektromosenergia-termelésben.

Az üvegházhatású gázok kibocsátásának 20 száza-

2020

lékos csökkentése az 1990-es szinthez képest, a megújuló energia 20 százalékos részarányának megvalósítása a teljes energiafelhasználásban.

Energia 2020

(EB [2010])

20 százalékos energiahatékonyság-javulás;

a megújuló energia 20 százalékos részarányának megvalósítása a végső energiafelhasználásban; az üvegházhatású gázok kibocsátásának 20 százalékos csökkentése az 1990-es szinthez képest.

Éghajlat- és energiapolitikai keret a 2020-2030-as időszakra (EB [2014])

Az üvegházhatású gázok kibocsátásának 40 százalékos csökkentése az 1990-es szinthez képest; a megújuló energia 27 százalékos részarányának megvalósítása a végső energiafelhasználásban; 25 százalékos energiahatékonyság-javulás.
A 2030-ig tartó időszakra vonatkozó éghajlat- és energiapolitikai keret (ET [2014])

Az üvegházhatású gázok kibocsátásának 40 százalékos csökkentése az 1990-es szinthez képest; a megújuló energia 27 százalékos részarányának megvalósítása a végső energiafelhasználásban; 27 százalékos energiahatékonyság-javulás.

Forrás: saját szerkesztés.

2005-re egyre inkább erősödött az igény az Európai Unión belül egy egységes, hoszszú távú energiapolitika kialakítása iránt, aminek fö oka az olaj árának emelkedése volt. Az Európai Bizottság ennek hatására 2005-ben és 2006-ban jelentetett meg zöld könyvet ( $E B$ [2005], [2006a]) az energiahatékonyságról (EB [2005]), illetve a fenntartható energiaellátást, versenyképességet és biztonságot szolgáló európai stratégia, majd a közösségi energiapolitikát máig meghatározó dokumentumokat, 
az energiahatékonysági cselekvési tervet ( $E B$ [2006b]) és az európai energiapolitikát (EB [2007b]). A zöld könyvekben meghatározott, előretekintő szakpolitikai programok az energiapolitika három központi célkitüzésére, nevezetesen a fenntarthatóságra, a versenyképességre és az ellátás biztonságára irányulnak, e három fö kérdés köré építik fel a végrehajtandó feladatokat.

Az említett négy dokumentum alakította ki azt a keretrendszert, amely az Energia 2020 címü dokumentumban (EB [2010]) foglalt 20-20-20-as célkitüzések megfogalmazásához vezetett (ezekre a későbbiekben részletesen kitérünk). A 2005. évi zöld könyv, illetve az energiahatékonysági cselekvési terv legalább 20 százalékos uniós energiahatékonysági teljesítőképesség-növekedést tartalmaz, az energiahatékonyság fejlesztése nélkül a nem megfelelö hatékonyságú energiafelhasználás évente körülbelül 60-100 milliárd euró közvetlen költséget jelent (vagyis ekkora összeg válna megtakaríthatóvá). Az EB [2006a] zöld könyv további lehetőségeket azonosít a teljesítőképesség terén, így a dokumentum szerint 2010-re megvalósítható az, hogy az Európai Unió a megújuló energia részarányát 21 százalékra növelje az elektromosenergia-termelésében. Az EB [2007b] még egy további területen tett konkrét vállalást, így célul tüzte ki az üvegházhatású gázok kibocsátásának 20 százalékos csökkentését az 1990-es szinthez képest, továbbá pontosította a megújuló energiaforrásokra vonatkozó tervet (2020-ig 20 százalékra kell növelni a részesedésüket a teljes energiafelhasználásban).

A 2006/32/EK irányelv - amely felszólítja a tagállamokat a nemzeti energiahatékonysági célelőirányzatok meghatározására - a kezdeményezések tagállami szintű megvalósítására összpontosított (Európai Parlament és Tanács [2006]). A megújulóenergia-útiterv (EB [2007c]) tartalmazta az Európai Uniónak a megújuló energiaforrásokra vonatkozó hosszú távú stratégiáját. Ennek részletes kidolgozására azért volt szükség, mert - ahogy azt a helyzetértékelés során a dokumentum készítői megállapítják - a publikálást megelőző tíz évben csekély előrelépés történt a megújuló energia használata terén, és kétségesnek látszott az 1997-es fehér könyvben tett, a 12 százalékos végső felhasználásbeli részarány 2010 -es célkitüzésének elérése (EC [1997]).

Az Európai Unió 2008-as energiaellátási cselekvési terve határozta meg a későbbi 20-20-20-as célok pilléreit: a hangsúlyt az infrastruktúra és az energiaügyi külkapcsolatok fejlesztésére, az energiaellátás diverzifikálására, válságkezelési mechanizmusok kialakítására, az energiahatékonyságra, illetve az EU saját energiaforrásainak lehető legjobb kiaknázására helyezte (EB [2008]).

Az ezredfordulót követően egyre intenzívebbé váltak a klímaváltozás lehetséges okait és következményeit vizsgáló kutatások. Az éghajlat-változási kormányközi testület (Intergovernmental Panel on Climate Change, IPCC) közleményei vagy például a 2006 októberében publikált Stern-jelentés, továbbá a klímacsúcsok sikertelensége arra ösztönözte az integráció képviselöit, hogy határozottan állást foglaljanak a témában. Az éghajlatváltozáshoz való alkalmazkodásról szóló $E B$ [2009] fehér könyv az EB [2007a] zöld könyv folytatásának tekinthetö. A lehetőségek azonosításán túl egy olyan keretet határozott meg, amelynek segítségével csökkenthető az Európai Unió sebezhetősége a klímaváltozással szemben. 
Az említett dokumentumokban meghatározott tervek és célkitűzések folytatásaként adták közre 2010-ben az Energia 2020 stratégiát, amelynek keretében az Európai Unió kötelezte magát, hogy 2020 -ig 368 millió tonna kőolajnak megfelelő mennyiségü elsődleges energia (a nem energia célú felhasználással csökkentett teljes belső energiafogyasztás) megtakaritását éri el, ami 20 százalékos megtakarítást jelent a 2020-ra vonatkozó elörejelzésekhez képest (EB [2010]). A megújuló energiaforrások részarányát a végső energiafelhasználásban szintén 20 százalékra kell növelni 2020 -ig, továbbá ugyanilyen nagyságrendü célkitűzést határozott meg az integráció az üvegházhatású gázok kibocsátása tekintetében (itt az 1990-es szint szolgál az összehasonlítás alapjául). Ezeket a számokat természetesen nem minden tagállamnak kell elérni, a fő feladat, hogy átlagosan teljesüljenek ezek a célok. Ebből adódóan jelentős különbségek vannak az egyes tagállamok vállalásait tekintve, például míg Málta 10 százalékban határozta meg a megújuló erőforrások 2020 -ig elérendő részarányát, addig Svédország 49 százalék elérését tüzte ki (Függelék F1. táblázat). A későbbiekben e három cél tekintetében vizsgáljuk a tagok közötti konvergenciafolyamatokat.

A jogalkotási mechanizmus ezt követően sem lassult le: az energiahatékonysági célkitüzés részletes leírását az Európai Bizottság Energiahatékonysági terv címü dokumentumát 2011 márciusában tette közzé (EB [2011a]). Ugyanakkor a szakértők nem minden célkitűzés esetében ítélték elegendőnek az addig elért változásokat. Az említett dokumentum megállapítja, hogy „,a legújabb becslések arra engednek következtetni, hogy az Európai Unió jelenlegi erőfeszítései csak a 20 százalékos célkitűzés felének teljesítéséhez lesznek elegendőek" (EB [2011a] 1. o.). Mind ennek, mind az EB [2011b] dokumentumnak - amely az alacsony szén-dioxid-kibocsátású, versenyképes gazdaság 2050-ig történő megvalósításáról szól - az egyik fő megállapítása, hogy az energiahatékonyság az erőforrás-hatékony gazdaság elengedhetetlen feltétele, s e téren a legnagyobb lehetöségek a háztartási (épületek) és a közlekedési szektorban rejlenek. Az Európai Bizottság által 2011. év végén elfogadott 2050-ig tartó energia-útiterv (Roadmap [2009]) szerint a javuló energiahatékonyság eredményeképp az energiafogyasztás 2050-re 40 százalékkal fog csökkenni a 2005-2006-os csúcshoz képest.

Az Európai Bizottság 2013 márciusában közzétette újabb zöld könyvét, amelyben vázolta az éghajlat- és energiapolitikai kereteket 2030-ra (EB [2013]). Ennek folytatását, a 2020-2030-as időszakra szóló éghajlat- és energiapolitikai kereteket, 2014 januárjában publikálta ( $E B$ [2014]). Ebben az eddig elért eredmények összegzésén túl három új, 2030-ig elérendő célt határozott meg. Így 40 százalékkal kívánják csökkenteni az üvegházhatású gázok kibocsátását (az 1990-es szinthez képest), illetve 27 százalékra tervezik növelni a megújuló energiaforrásokból előállított energia arányát (a végső energiafelhasználásban). Az energiahatékonysági célok elérése tekintetében ugyanakkor a közlemény szerint továbbra is jelentős lemaradás tapasztalható: „a jelenlegi előrejelzések szerint a célkitűzéshez képest 20 százalékos elmaradásra lehet számítani”. Emiatt a Bizottság óvatosabban fogalmaz, 25 százalékos hatékonyságjavulásról ír. 2014 októberében az Európai Tanács elfogadta az integráció új klíma- és energiastratégiáját, amelyben az említett célszámok megmaradtak, sőt az energiahatékonyságot tekintve még a mbiciózusabbá (27 százalékra emelték az uniós célt) váltak (ET [2014]). 


\section{Elméleti háttér}

A közgazdaságtan nemcsak más tudományágaktól kölcsönöz gyakorta módszereket (például a fizikai, biológiai, illetve kémiai tudományoktól), hanem ezen belül is megfigyelhető az egyes - egymással sok esetben versengő - területek határainak elmosódása, a módszertanok alkalmazása más területen. A konvergenciaszámítások más területeken való alkalmazásáról Quah [1996] megállapítja, hogy a konvergencia problémája alapvetően empirikus kérdés, amelynek középpontjában a polarizáció, a jövedelemelosztás és a jövedelmi egyenlőtlenségek témakörei állnak. Bizonyos, hogy a gazdasági növekedés megértése egy nagyon fontos dolog, de a növekedés a közgazdaságtannak mindössze egy szelete, számos olyan terület van, ahol ezek az elemzések hasznos adalékkal szolgálhatnak. Ezzel indokolható, hogy a nemzetek közötti konvergencia mérésének témaköre Barro [1991], valamint Barro-Sala-i-Martin [1992] megjelenése óta kiemelt érdeklödésre tart számot. ${ }^{1}$

Oblath-Szörfi [2008] szerint „a konvergencia (felzárkózás) - szűkebb értelemben - a kevésbé fejlett országok reálgazdasági teljesítményének közeledését jelenti a fejlettebb országokéhoz", tágabb értelemben az általános makrogazdasági jellemzők közeledését (205. o.). A konvergenciaszámításokat ma már számos területen alkalmazzák, így a szegénység, a jövedelmi különbségek, az emberi erőforrások vizsgálatának egyik gyakori eszköze. Az energia- és környezet-gazdaságtan eszköztárában alig egy évtizede jelentek meg ezek a számítások, de e rövid idő alatt is számos tanulmány született, és komoly fejlődés ment végbe az alkalmazott adattípusok, illetve módszertan tekintetében.

A konvergenciaszámítások energetikai alkalmazásában úttörö munkának számít a Mielnik-Goldemberg [2000] tanulmány, amelyben a szerzők egyszerü leíró statisztikával, illetve diagramok segítségével vizsgálták 41 ország energiaintenzitásának alakulását 1971 és 1992 között. Markandya és szerzőtársai [2006] az Európai Unió 15 „régi”, illetve a 2004. évi és 2007. évi bővítés során csatlakozott országok energiaintenzitása közötti konvergenciát vizsgálja. Arra kereste a választ, hogyan halad előre a 2020. évi 20 százalékos célkitűzés megvalósítása az integrációban. Eredményei alátámasztják a kiinduló hipotézist, a később csatlakozott tagállamok felzárkózása sikeresnek tekinthető energetikai szempontból. Ezcurra [2007] 98 ország energiaintenzitására azonosított csökkenő mértékű konvergenciát 1971 és 2001 között.

Szintén az energiaintenzitást vizsgálta Liddle [2012]: 28 OECD-ország esetében igazolta a $\sigma$-, az abszolút $\beta$-, illetve a $\gamma$-konvergenciát. A szerző egy korábbi tanulmánya a Nemzetközi Energiaügynökség 22 fejlett tagországának egységnyi GDP-re jutó elektromosenergia-felhasználását nem nemzetgazdasági, hanem ágazati (kereskedelem, illetve az ipari és a háztartási szektor) szinten vizsgálta (Liddle [2009]). Az indikátor választását az indokolta, hogy a hagyományos energiaintenzitási mérőszám túlságosan tág kategória, nem ad választ arra a kérdésre, hogy hasonló fejlettségü országok

\footnotetext{
${ }^{1}$ Nemcsak a világ- és regionális gazdaságtan (lásd például Kocziszky [2010], Szendi [2013], BenedekVeress [2013]), a térgazdaságtan (lásd például Tóth-Nagy [2014]) kutatói körében, hanem az energia-, környezet- és ökológiai gazdaságtan esetében is (lásd például Szlávik [2013]).
} 


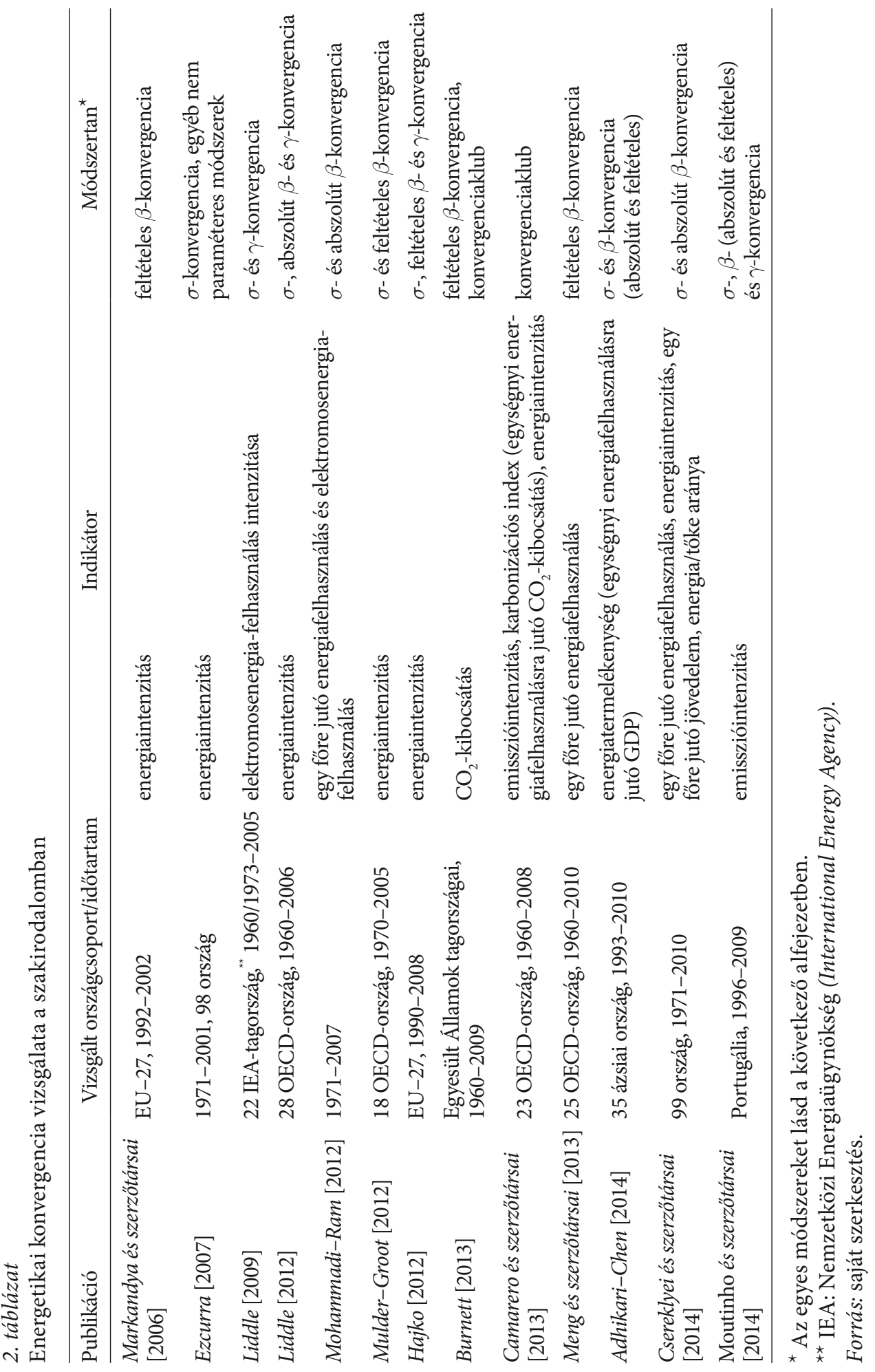


esetében miért is tér el gyökeresen az energiafelhasználás (ennek ellenére 2012-es tanulmányában a szerző visszatér a hagyományos energiaintenzitáshoz). Számításai igazolták a $\sigma$ - és $\gamma$-konvergenciát az említett szektorokban, bár sokkal kevésbé „látványos" az országok közötti összetartás ezen mutató esetében, mint ha az energiaintenzitást választotta volna. Szintén ágazati szintü elemzés Moutinho és szerzőtársai [2014], valamint Mulder-Groot [2012] (ez utóbbi a feldolgozóipar és a szolgáltató szektor esetében mind a $\sigma$, mind a $\gamma$-konvergenciát igazolta).

Csereklyei és szerzőtársai [2014] a korábbiakhoz képest jóval nagyobb mintán igazolta 99 ország esetében az energiaintenzitás konvergenciáját 1971 és 2010 között, pedig egyes országcsoportok esetében (Közel-Kelet és Afrika) a statisztikai adatok vizsgálatából inkább divergenciára következtethetünk. Rámutatott, hogy egymással ellentétes folyamatok zajlanak Észak-Afrikában és a szubszaharai Afrikában.

Az elmondottakat összefoglaltuk a 2. táblázatban.

Az általunk elvégzett elemzéshez hasonlóan Burnett [2013], illetve Camarero és szerzőtársai [2013] szintén konvergenciaklubok azonosításával igazolja a vizsgált országok közötti összetartást az emisszió esetében.

Tanulmányunk előzményének tekinthető Hajko [2012] publikációja, melyben a szerző az Európai Unió 27 tagállamának energiaintenzitására végez vizsgálatokat a $\sigma$ és a $\beta$-konvergenciára vonatkozóan. Eredményei szerint, míg az új tagállamok esetében 1990 és 2008 között fennáll a konvergencia, addig a régi tagállamok inkább divergenciát mutatnak az energiaintenzitásra vonatkozóan. Jelen tanulmány ugyanakkor számos ponton túllép ezeken a kereteken. Egyrészt legfontosabb célunk a már 28 tagállammal rendelkező integráció, illetve az egyes országok előrehaladásának értékelése a 20-20-20-as célok tükrében. Ezt szolgálja a vizsgálati időhorizont megváltoztatása, mellyel így már lehetőség nyílik a 2008-2009-es válság hatásainak figyelembevételére is. Az alkalmazott konvergenciamutatók körét is bővítjük, mely így teljesebb képet nyújt a jelenleg is zajló folyamatokról.

Felmerülhet a kérdés, hogy miért fontos az egyes országok energetikai jellemzőinek konvergenciavizsgálata. Először is a politikai döntéshozóknak tudniuk kell, hogy hosszú távon az energetikai indikátorok milyen irányú és mekkora elmozdulására számíthatnak. Ez segíthet az energiagazdálkodás feltételeinek alakításában, az előrejelzési modellek készitésében. Élénk az érdeklődés abban a tekintetben, hogy hosszú távon miként alakul a nemzetgazdaságok energiafelhasználása, elválik-e az a gazdasági növekedéstől. Amennyiben a magas energiaintenzitással rendelkező országok konvergálnak a fejlettebbekhez, vagyis az egyensúlyi érték alacsonyabb, akkor gyors ütemü összetartás és kiegyensúlyozott gazdasági növekedés mellett nem várható az energiafogyasztás hirtelen növekedése (Markandya és szerzőtársai [2006]).

\section{Módszertan}

Tanulmányunkban a konvergenciaszámításokat háromféle megközelítésben végezzük el: vizsgáljuk a $\sigma$-, $\gamma$-és a $\beta$-konvergenciát, továbbá, ahol ez utóbbi igazolást nyer, ott konvergenciaklubok számítására is sor kerül. A továbbiakban ezek módszertanát ismertetjük. 
1. A $\sigma$-konvergencia esetében az egyes országok keresztmetszeti adatainak szórásából következtetünk az egyes országok közötti összetartásra vagy széthúzásra. Ha az idő múlásával csökken az adott indikátor szórása segítségével számított $\sigma$-konvergencia, az a területi egységek konvergenciáját mutatja, azaz azt, hogy mennyire hatékony a rosszabbul teljesítő országok felzárkózása a fejlettebbekhez (Liddle [2012]). Hátránya, hogy a mutató értéke akkor is növekedhet, ha mindöszsze az adatok abszolút nagysága nő. A $\sigma$-konvergenciát a szórástényezö (coefficient of variation, $C V$ ) segítségével számítjuk, amely az adatok szórásának és számtani átlagának a hányadosa (Moutinho és szerzőtársai [2014]).

A $\sigma$-konvergencia képlete:

$$
C V=\frac{\sigma}{\bar{x}}, \quad C V_{t}<C V_{0},
$$

ahol $x_{i}$ a vizsgálatba bevont indikátor, $\bar{x}=x_{i}$ számtani átlaga, $\sigma$ a szórás, $C V$ a szórástényezö (coefficient of variation).

Elöfordulhat, hogy a $\sigma$-konvergencia értéke folyamatosan csökkenő tendenciát mutat (tehát a vizsgálatba bevont területi egységek konvergálnak), ugyanakkor a legmagasabb, illetve a legalacsonyabb kiindulási értékkel jellemezhető országok pozíciója nem változik a mintán belül. Az egyes országok adott mutató szerinti rangsorolásának figyelembevételére dolgozta ki Boyle-McCarthy [1997] és [1999] a $\gamma$-konvergenciát.

2. A $\gamma$-konvergencia az eloszláson belüli mobilitás mérésére alkalmas: az adott indikátor szempontjából fejletlenebb ország - amennyiben sikeres a felzárkózás - feljebb kerül a rangsorban, megelözve ezzel a jobban teljesítőket (míg azok veszítenek pozíciójukból). Azt, ha a $\gamma$-konvergencia nem mutatható ki, de a $\sigma$-konvergencia igen, úgy kell értelmezni, hogy bár a vizsgálati egységek közötti különbségek megmaradtak, de e különbségeknek a mértéke jelentősen csökkent (Liddle [2012]).

A $\gamma$-konvergencia képlete:

$\gamma=\frac{\operatorname{Variancia}\left(A S_{i t}+A S_{i 0}\right)}{\operatorname{Variancia}\left(2 \times A S_{i 0}\right)}$,

ahol $A S$ az aktuális sorrendet jelöli: $A S_{i t}$ az $i$-edik ország rangsorban betöltött pozíciója $t$-edik időpontban, $A S_{i 0}$ az $i$-edik ország rangsorban betöltött pozíciója a bázisidőszakban, a Variancia $=\frac{\sum(x-\bar{x})^{2}}{(n-1)}$,

ahol $\bar{x}$ az átlag, $n$ pedig a minta mérete. Minél kisebb a mutató értéke, annál erősebb az átrendeződés a vizsgált területi egységek között.

3. A $\beta$-konvergencia alapvető feltevése, hogy egy indikátor növekedési rátája nagyobb azokban az országokban, amelyeket eleve alacsonyabb érték jellemzett, és kisebb lesz ott, ahol magasabb volt a kiindulási érték. Ez hosszú távon azt eredményezi, hogy az adott indikátor szempontjából kevésbé fejlett országok felzárkóznak a jobban teljesítőkhöz. Major [2001] ezt részletesen vezeti le a Solow-modellből. Ez az energiaintenzitás esetében azt jelenti, hogy azok az országok, amelyek gazdaságát 
kezdetben relatíve magas energiaintenzitás jellemezte (vagyis nagyobb volt az egységnyi GDP-re jutó energiafelhasználás), a későbbiekben felzárkóznak a jobban teljesítő (hatékonyabb), fejlettebb országokhoz. Ha a $\beta$ értéke negatív, akkor fennáll az országok közötti $\beta$-konvergencia. Ugyanakkor a $\beta$-együttható negatív értéke csak szükséges, de nem elégséges feltétele a $\sigma$-konvergenciának (Boyle-McMcarthy [1997], [1999], Liddle [2012], Hajko [2012]).

A $\beta$-konvergencia képlete:

$\Delta \ln y_{i}=\alpha+\beta \ln y_{0}+\varepsilon_{i}$,

ahol $y$ a vizsgálatba bevont indikátor (például az energiaintenzitás), $\alpha$ a konstans tag, $\beta$ a regressziós együttható, 0 a bázisidőszak, $i$ az adott ország indexe, $\varepsilon_{i}$ a hibatag (melynek várható értéke nulla).

A $\beta$-konvergencia esetében megkülönböztetünk abszolút és feltételes konvergenciát. Az előbbi esetében az egyes országok adatai ugyanazon egyensúlyi érték felé közelednek. Míg a feltételes konvergencia esetében a gazdaságok nem egymáshoz, hanem sokkal inkább a saját egyensúlyi pályájukhoz (minden ország saját növekedésének hosszú távú egyensúlyi állapota felé) konvergálnak. Fontos különbség az abszolút és a feltételes konvergencia között, hogy az előbbi esetében azok az országok, amelyeket kezdetben például rosszabb energiahatékonyság jellemzett, gyorsabban fejlödnek, mint azok a gazdaságok, amelyek eleve jobban teljesítettek (Gáspár [2010]). A feltételes konvergencia akkor áll fenn, ha például az energiahatékonyság növekedési rátájának folyamatos csökkenése figyelhető meg az egyes gazdaságokban, ahogy közelednek saját hosszú távú egyensúlyi állapotaikhoz (Burnett [2013]).

A továbbiakban az abszolút konvergencia számítását alkalmazzuk. Ez azzal indokolható, hogy az Európai Unió a 2020-as célokkal tulajdonképpen egy közös egyensúlyi értéket határozott meg, amelynek kitüzése során figyelembe vették a tagállamokban ('́gy az integráció egészében) rejlő lehetőségeket, a strukturális eltéréseket, a termelési tényezők árának várható alakulását, a technológiai fejlődést, a meglévő szabályozási környezetet. Tehát a vizsgálat során arra a kérdésre keressük a választ, hogy képesek-e a tagországok e mesterségesen kialakított, közös egyensúlyi érték felé tartani, tapasztalható-e közeledés közöttük.

A konvergencia további értelmezését segíti a konvergenciaklub fogalma: egy-egy konvergenciaklubba olyan gazdaságok tartoznak, amelyek hosszú távú növekedési pályája egymáshoz közeliek, vagyis egyfajta homogenitást mutatnak társadalmi, gazdasági szempontok alapján (Kocziszky és szerzőtársai [2014]). A megközelítés lényege, hogy a vizsgált gazdaságok egyfajta csoportosulást mutatnak egy adott változó szempontjából, amely szerint megfigyelhető a csoportokon belüli konvergencia. Az elemzés célja olyan csoportok kialakítása, amelyek minimalizálják a csoportokon belüli, és maximalizálják az egyes csoportok közötti különbségeket (Szendi [2013]). A legfontosabb különbség a feltételes és a klubkonvergencia között, hogy míg az előbbi esetében a vizsgált gazdaságok egy közös (globális), addig az utóbbi esetében az egyes klubokhoz tartozó területi egységek egy lokális hosszú távú egyensúlyi (steady state) állapot felé tartanak. A klubkonvergencia esetében tehát „nem 
strukturális változók, hanem az egyes országok között megfigyelhetö, pontosabban egyes országok csoportjára vonatkozó kezdeti feltételek azok, melyek meghatározzák a konvergenciafolyamatokat" (Gáspár [2010] 2. o.).

Az Európai Unió 28 tagállama esetében konvergenciaklubok fennállását - az abszolút $\beta$-konvergencia módszeréből és eredményeiből kiindulva - hierarchikus klaszterelemzéssel vizsgáljuk. Az alkalmazott elemzési eljárás a Ward-módszer, amely a varianciaalapú, összevonáson alapuló modellek közé sorolható. Ez azt jelenti, hogy a folyamat megkezdésekor minden egyes elem önálló klasztert alkot. Az eljárás célja az optimális klaszterek megállapítása olyan módon, hogy a klasztereken belüli szórásnégyzet növekedése a legkisebb legyen. Tekintettel arra, hogy különböző metrikus skálákkal dolgozunk, ezért szükség van a különböző szintű skálák azonos szintre hozására, vagyis standardizálására. A módszer alkalmazása során az átlagot kivonjuk az egyes értékekből, majd a különbséget osztjuk a szórással. Az így standardizált skálán az átlag értéke 0, szórása 1 lesz (Sajtos-Mitev [2007]).

\section{Eredmények}

Számításainkhoz az Eurostat 2015. évi (http://ec.europa.eu/eurostat/data/database) és a Világbank 2015. évi (www.worldbank.org) adatbázisát használjuk fel. A tanulmányban a 2004, 2007 és 2013 során kibővült Európai Unió 28 tagállamát vizsgáljuk, továbbá különbséget teszünk régi és új tagállamok között. ${ }^{2}$ Ezt egyrészt a jelentős fejlettségi különbségek (az egy före jutó GDP tekintetében), másrészt az eltérő történelmi múltból származó energetikai különbségek indokolják. A vizsgált adatok az Energia 2020 stratégiában megfogalmazott vállalások kulcsindikátoraihoz köthetök:

- a gazdaság energiaintenzitása [a bruttó belföldi energiafelhasználás aránya a 2005. évi árakon mért GDP-hez viszonyítva; klímával korrigált hasznos energia (koe)/ ezer euró; forrás: Eurostat];

- emisszióintenzitás (az üvegházhatású gázok kibocsátásának aránya a 2011.évi árakon mért, vásárlóerö-paritásos GDP-hez viszonyítva; 1 tonna $\mathrm{CO}_{2}$-egyenérték/ ezer dollár; forrás: Világbank);

- a megújuló energiaforrások aránya a végső energiafelhasználásban (százalék; forrás: Eurostat).

Az első két mutató esetében a vizsgált időtartam 2001-2012, de a megújuló energiaforrások részarányára vonatkozóan csak 2004-töl érhetők el adatok az Eurostat adatbázisában, így ebben az esetben az idősor a 2004-2012-es időszakot fogja át.

${ }^{2}$ „Régiek”: Franciaország (FRA), Németország (DEU), Belgium (BEL), Luxemburg (LUX), Hollandia (NLD), Olaszország (ITA), Nagy-Britannia (GBR), Írország (IRL), Dánia (DNK), Görögország (GRC), Spanyolország (ESP), Portugália (PRT), Ausztria (AUT), Svédország (SWE), Finnország (FIN).

„Újak”: Ciprus (CYP), Málta (MLT), Észtország (EST), Lettország (LVA), Litvánia (LTU), Lengyelország (POL), Csehország (CZE), Szlovákia (SVK), Magyarország (HUN), Szlovénia (SVN), Románia (ROM), Bulgária (BGR), Horvátország (HRV).

A zárójelben a Világbank által is alkalmazott rövidítések. 
A $\beta$-konvergencia számítása során az energiaintenzitás, illetve az üvegházhatású gázok egységnyi GDP-re jutó kibocsátásának inverzét alkalmaztuk - hasonlóan Adhikari-Chen [2014]-hez -, mivel így szemléletesebb, hogy a mutatók növekedése valójában romlást jelent. Tehát a mutató inverzének alkalmazásával az emelkedés ebben az esetben fejlődést, a teljesítmény javulását mutatja. A későbbiekben az energiaintenzitás inverzét energiahatékonyságnak nevezzük, míg az üvegházhatású gázok egységnyi GDP-re jutó kibocsátásának inverze nem más, mint az emisszióintenzitás inverze.

A 3. táblázat egyszerủ leíró statisztikával mutatja be a három indikátor alakulását 2001-2012, illetve 2004-2012 között.

\section{3. táblázat}

Főbb statisztikai adatok az Európai Unió régi és új tagországai esetében

\begin{tabular}{|c|c|c|c|c|c|c|}
\hline & \multicolumn{2}{|c|}{$\begin{array}{l}\text { Energiaintenzitás } \\
\text { (koe/1000 euró) }\end{array}$} & \multicolumn{2}{|c|}{$\begin{array}{c}\text { Üvegházhatású } \\
\text { gázok kibocsátása } \\
1990=100\end{array}$} & \multicolumn{2}{|c|}{$\begin{array}{l}\text { Megújuló energia- } \\
\text { források részaránya } \\
\text { a végső energia- } \\
\text { felhasználásban }\end{array}$} \\
\hline & 2001 & 2012 & 2001 & 2012 & 2004 & 2012 \\
\hline \multicolumn{7}{|l|}{ Átlag } \\
\hline EU-28 & 298,87 & 221,86 & 94,10 & 86,08 & 11,38 & 16,87 \\
\hline EU-15 (régi tagországok) & 159,91 & 136,49 & 109,07 & 93,50 & 11,98 & 18,44 \\
\hline Új tagországok & 437,82 & 307,23 & 79,14 & 78,67 & 10,79 & 15,31 \\
\hline \multicolumn{7}{|l|}{ Medián } \\
\hline EU-28 & 197,40 & 166,35 & 98,73 & 84,25 & 7,65 & 13,65 \\
\hline EU-15 (régi tagországok) & 159,60 & 139,65 & 104,68 & 89,59 & 7,60 & 13,65 \\
\hline Új tagországok & 432,85 & 295,15 & 77,64 & 65,51 & 8,30 & 13,75 \\
\hline \multicolumn{7}{|l|}{ Minimum } \\
\hline EU-28 & 103,30 & 82,80 & 40,50 & 42,92 & 0,30 & 2,70 \\
\hline EU-15 (régi tagországok) & 103,30 & 82,80 & 85,26 & 76,55 & 1,20 & 4,20 \\
\hline Új tagországok & 147,40 & 133,80 & 40,50 & 42,92 & 0,30 & 2,70 \\
\hline \multicolumn{7}{|l|}{ Maximum } \\
\hline EU-28 & 1040,10 & 669,90 & 144,72 & 156,90 & 38,70 & 51,00 \\
\hline EU-15 (régi tagországok) & 234,80 & 204,00 & 137,88 & 122,48 & 38,70 & 51,00 \\
\hline Új tagországok & 1040,10 & 669,90 & 144,72 & 156,90 & 32,80 & 35,80 \\
\hline \multicolumn{7}{|l|}{ Szórás } \\
\hline EU-28 & 217,35 & 132,98 & 29,20 & 28,53 & 10,11 & 11,51 \\
\hline EU-15 (régi tagországok) & 36,19 & 32,83 & 15,65 & 14,94 & 11,50 & 13,52 \\
\hline Új tagországok & 235,00 & 141,26 & 32,30 & 36,72 & 8,91 & 9,32 \\
\hline
\end{tabular}

Forrás: az Euróstat adatai alapján saját szerkesztés. 
A tagállamok energiaintenzitásában jelentős javulás tapasztalható: mind a régi, mind az új tagországok átlagában javult a mutató értéke. Az üvegházhatású gázok kibocsátásának intenzitására az Európa 2020 célkitüzése: az 1990-es kibocsátási szinthez képest 20 százalékos csökkenés. E mutató alakulását vizsgáljuk ugyan, de bázisviszonyszámként a későbbi elemzésbe már nem tudjuk bevonni (így ott a hasonló emisszióintenzitásra vizsgáljuk). Az emisszió a leíró statisztikák szerint általában javult (jóllehet kisebb mértékben, mint az energiaintenzitás), bár a minimum- és a maximumértékek romlottak, az előbbi Lettország, az utóbbi Málta és Ciprus miatt. Ez kihat az új tagországoknál mért szórásra is, ahol több mint 13 százalékos a növekedés. A megújuló energiaforrások részesedése minden tekintetben javulást mutat, bár a tagállamok szórása is növekedett.

\section{Konvergenciaszámitások a gazdaság energiaintenzitása esetében}

Az 1. ábrát tekintve, az Európai Unió 28 tagálla mában az energiaintenzitás alakulása egészen 2008-ig igazolja a $\sigma$-konvergenciát, és ez igaz mind az integráció egészére, mind az új tagországokra. Ugyanakkor 2009 után e kedvező folyamatok megfordultak, enyhe divergencia figyelhető meg, nőttek a tagországok közötti különbségek. Ennek fö oka, hogy 2009-ben az elöző évhez képest 10 tagállamban jelentősen romlott a gazdaság energiaintenzitása (köztük Magyarországon is), 18 országban tapasztalható javulás. Egy évvel később (ebből a 18 tagállamból) már csak Görögország, Spanyolország és Ciprus képes a gazdaság hatékonyságán javítani, bár ez sem az energetikai beruházásoknak, hanem a gazdasági visszaesésnek „köszönhető”. A tendencia azonban átmeneti, 2011-től ezek a kilengések megszűnnek, újra a hatékonyságjavulás válik általánossá Európa-szerte. A régi tagállamok esetében ugyanakkor szinte nem változik az adatok szóródása, vagyis az egyenlőtlenségek állandósulni látszanak (sőt 2009-től még növekednek is). A $\gamma$-konvergencia jelenléte nem igazolható az integráció egészében (ez valószínüleg a vizsgált időtartam rövidségével magyarázható). Tehát a vizsgálati egységek közötti különbségek megmaradtak (nem volt jelentős átrendeződés a sorrendiséget tekintve), de e különbségek mértéke jelentősen csökkent.

A vizsgált 12 évet tekintve az Európai Unió 28 tagállamában összességében jellemző a kezdeti energiahatékonyság és annak változása közötti negatív kapcsolat, vagyis a regressziós egyenlettel számított $\beta$ negatív értéke mind az integráció egészében, mind az új tagállamok esetében a gyengébben teljesítő országok felzárkózását mutatja (kimutatható a $\beta$-konvergencia). E kapcsolat a 2004-ben, 2007-ben, illetve 2013-ban csatlakozott országokra nézve sokkal erősebb, mint az EU-28 egészére. A régi tagországok esetében a $\beta$ értéke nem szignifikáns (4. táblázat).

Mivel a $\beta$-konvergencia jelenléte igazolható az integrációban 2001-2012 között, így a továbbiakban a konvergenciaklubok azonosítását végezzük el. A számításokat három, illetve négy klaszterre vonatkozóan is lefuttattuk (a 2. ábrán mindkét eredményt feltüntettük).

Mindkét esetben elkülönül Bulgária (1. klaszter), amely nagyon rossz energiaintenzitási értékről indult 2001-ben, ugyanakkor kiemelkedően jól teljesített a vizsgált időszakban (bár nem szabad figyelmen kívül hagyni a tényt, hogy alacsonyabb 


\section{1. ábra}

$\gamma$ - és $\sigma$-konvergencia a gazdaság energiaintenzitása esetében

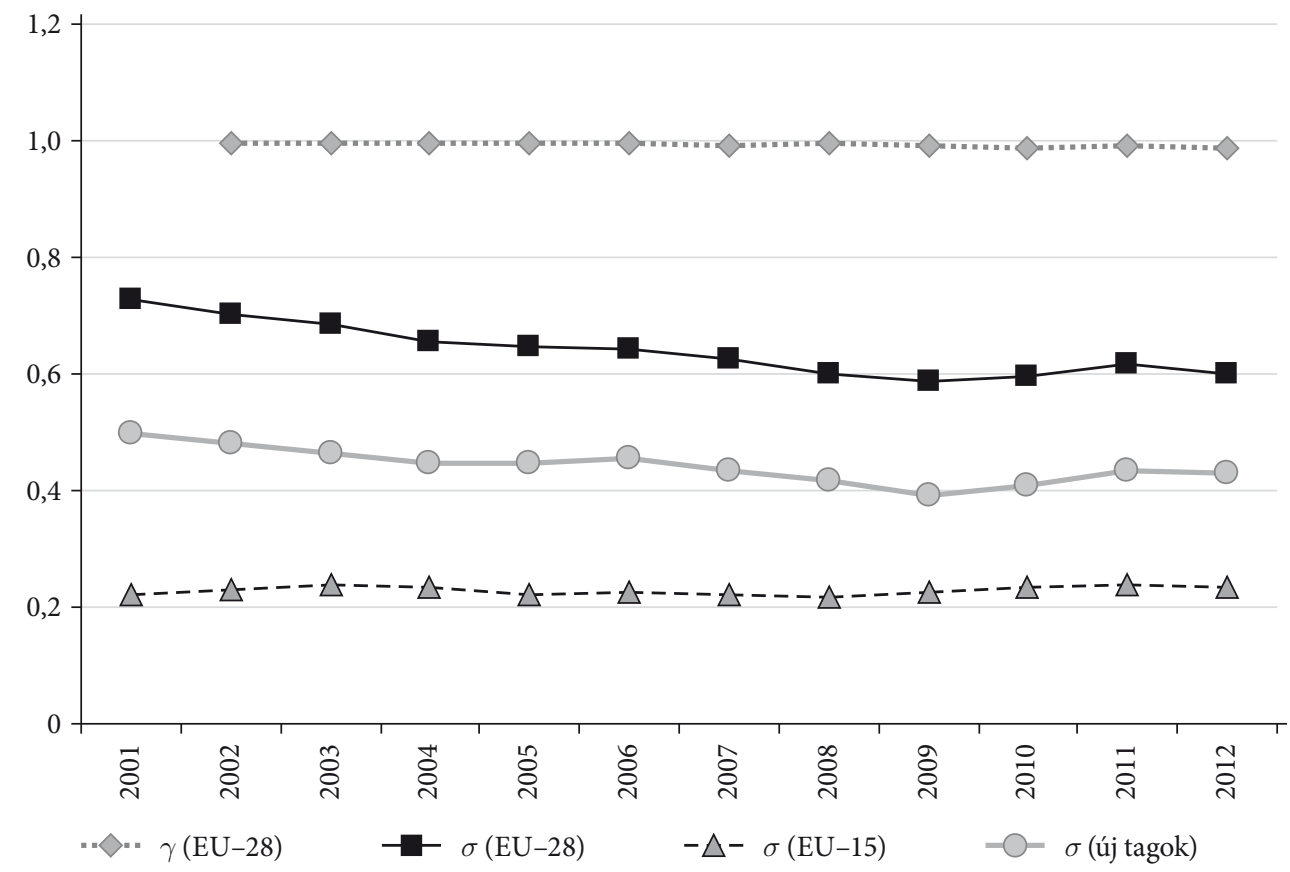

Forrás: saját szerkesztés.

4. táblázat

$\beta$-konvergencia az Európai Unió 28 tagállamában az energiahatékonyság esetében

\begin{tabular}{|c|c|c|}
\hline & $\beta$ & t-érték \\
\hline \multicolumn{3}{|l|}{$E U-28$} \\
\hline Konstans & 8,23806 & $0,0001^{\star * *}$ \\
\hline$\beta$ & $-1,15462$ & $0,0023^{* * *}$ \\
\hline Korrigált $R^{2}$ & \multicolumn{2}{|c|}{0,277422} \\
\hline \multicolumn{3}{|l|}{$E U-15$} \\
\hline Konstans & 0,987372 & $0,0523^{*}$ \\
\hline$\beta$ & $-0,0366974$ & 0,6023 \\
\hline Korrigált $R^{2}$ & \multicolumn{2}{|c|}{$-0,053797$} \\
\hline \multicolumn{3}{|l|}{ Új tagok } \\
\hline Konstans & 13,1675 & $0,0046^{* * *}$ \\
\hline$\beta$ & $-3,02221$ & $0,0333^{\star *}$ \\
\hline Korrigált $R^{2}$ & \multicolumn{2}{|c|}{0,290387} \\
\hline
\end{tabular}

*** 1 százalékos szinten, ${ }^{\star *} 5$ százalékos szinten, ${ }^{\star} 10$ százalékos szinten szignifikáns.

Forrás: saját szerkesztés. 


\section{2. ábra}

Konvergenciaklubok az energiahatékonyság esetében

Energiahatékonyság éves átlagos változása (százalék)

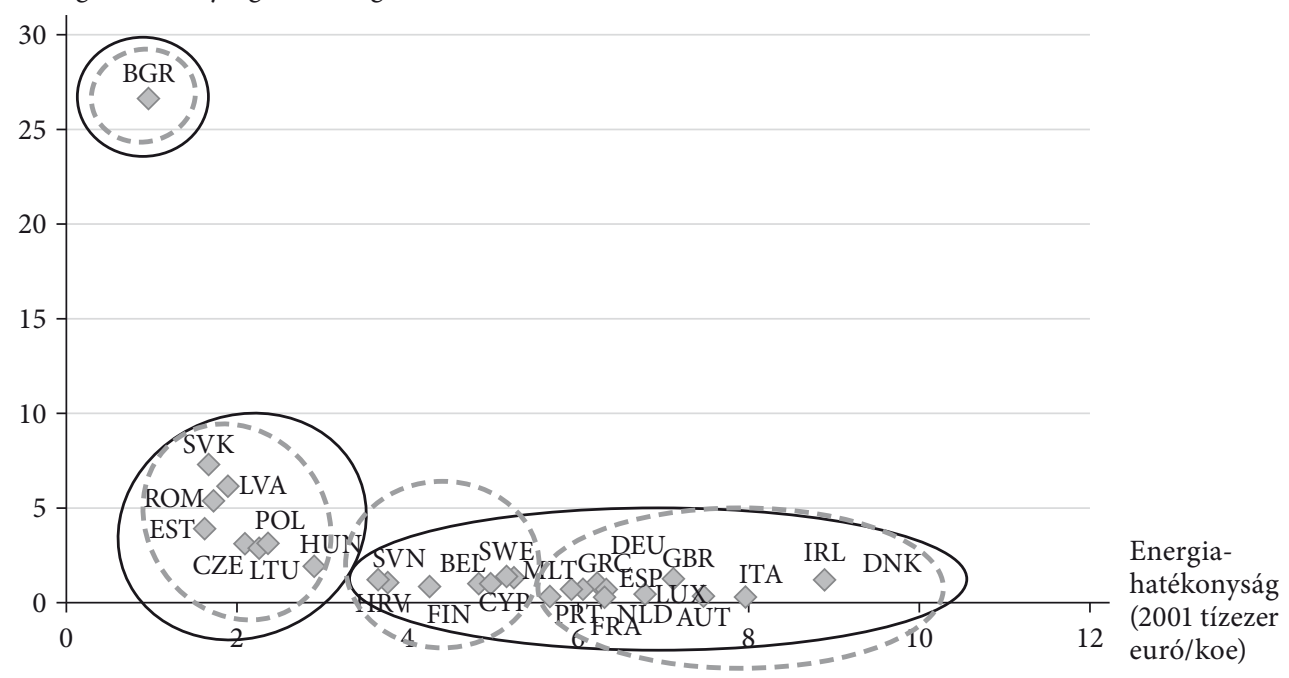

Megjegyzés: az országrövidítéseket lásd a 2. lábjegyzetben.

Forrás: saját szerkesztés.

fejlettségi fokról indulva könnyebb jelentősebb javulást elérni). A 2. klaszterbe Románia, Csehország, Magyarország, Lengyelország, Szlovákia, Észtország, Lettország és Litvánia tartozik. Rossz energiahatékonysági értékek jellemzik őket (az egységnyi energiafelhasználásra jutó GDP a 3. klaszterrel összehasonlítva alacsonyabb értékeket mutat), és csak kismértékü az elmozdulás a vizsgált időtartam alatt. A 3. klasztert két alcsoportra oszthatjuk (attól függően, hogy hány klasztert tartunk optimálisnak): az egyik alcsoportba Belgium, Finnország, Svédország, Ciprus, Horvátország, Málta és Szlovénia tartozik, a másikba Írország, Görögország, Spanyolország, Franciaország, Olaszország, Luxemburg, Hollandia, Ausztria, Portugália, Nagy-Britannia, Dánia és Németország. Az előbbi országok energiahatékonysága jobb értékeket mutat az 1. és 2. klaszterrel összehasonlítva, bár az elmozdulás mértéke rosszabb. Az utolsó csoportba (4. klaszter) tartozó országok nemzetgazdaságának energiaintenzitása a legjobb az Európai Unióban, amely azonban stagnál, elmozdulás alig figyelhető meg.

\section{Konvergenciaszámítások az üvegházhatású gázok kibocsátása esetében}

Csökkenő tendencia figyelhető meg az emisszióintenzitás szóródásának alakulásában ( $\sigma$-konvergencia) 2001 és 2008 között, ami azt jelenti, hogy csökkentek az egyenlötlenségek, vagyis teljesül a konvergencia (3. ábra). 2009-től a folyamatok megfordulni látszanak, a divergencia erősödik, ami azonban egy átmeneti (kétéves) periódusnak bizonyul. Ebben a rövid időszakban (2009-2010) tíz tagállamnak sikerült - a gazdasági visszaesés ellenére is - folyamatosan javítani a mutatón, a többi országban 
legalább egy évben nőtt a mutató értéke. Ugyanakkor 2011-ben Bulgária, Görögország, Spanyolország és Portugália emisszióintenzitási mutatója továbbra is romlott. Ennek fő oka, hogy ezekben az országokban a bruttó hazai termék csökkenése meghaladta az üvegházhatású gázok kibocsátásának visszaesését.

3. ábra

$\gamma$ - és $\sigma$-konvergencia az emisszióintenzitás esetében

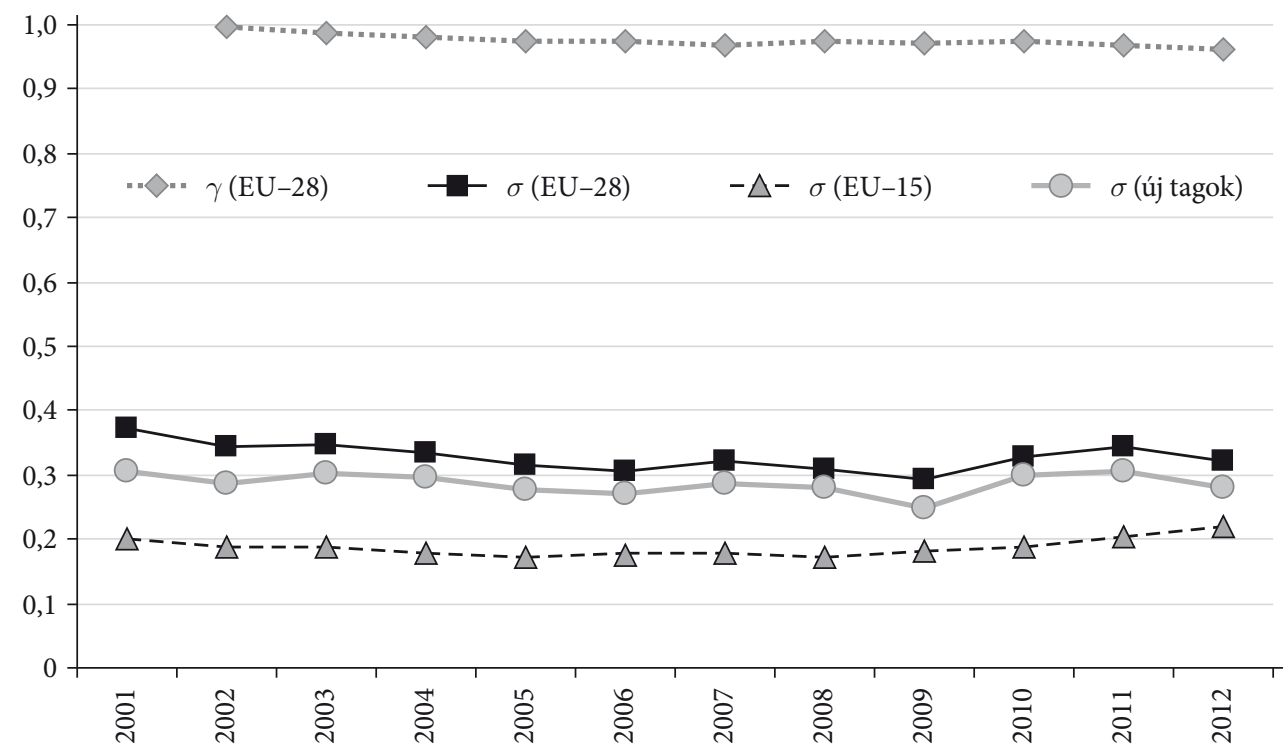

Forrás: saját szerkesztés.

A $\gamma$-konvergencia jelenléte is igazolható, bár a folyamat elég gyengének tekinthetö, a tagok közötti átrendeződés csak kismértékü a vizsgált 12 év során.

A regressziós egyenlet $\beta$-ja szerint a rosszabb emisszióintenzitási értékekkel induló tagállamok a hosszú távú (közös) egyensúlyi állapothoz gyorsabban konvergálnak, vagyis a kevésbé fejlett országok növekedési rátája magasabb, mint a fejletteké, tehát igazolható a konvergencia az Európai Unió egészében (5. táblázat). Ez az eredmény összhangban van azzal, amire a $\sigma$-konvergencia leírása során következtettünk. Az új tagországok esetében a folyamat még erősebb, de a régi tagállamoknál - hasonlóan az energiahatékonysághoz - a $\beta$ értéke nem szignifikáns.

Az energiahatékonysághoz hasonlóan az emisszióintenzitás inverzére vonatkozóan is elvégeztük a konvergenciaklubok azonosítását (4. ábra). Szintén három, illetve négy klasztercsoport kialakítása mellett döntöttünk. Önálló klubot képez mindkét esetben Svédország, amely esetében kiemelkedően alacsony az egységnyi GDP-re jutó üvegházhatású gázok kibocsátása, ráadásul folyamatos javulás volt tapasztalható a vizsgált 12 évben. A 2. klubot (amennyiben a négy klasztert nézzük) Dánia, Németország, Spanyolország, Franciaország, Olaszország, Luxemburg, Hollandia, Ausztria, Portugália és Málta alkotja. Szintén kiemelkedően jó a nemzetgazdaságuk emisszióintenzitása, ami kismértékben még javult is az eltelt időszakban. 


\section{5. táblázat}

$\beta$-konvergencia az Európai Unió 28 tagállamában az emisszióintenzitás esetében

\begin{tabular}{lcc}
\hline & \multicolumn{1}{c}{$\beta$} & $t$-érték \\
\hline$E U-28$ & 9,69192 & $0,000^{* * *}$ \\
Konstans & $-2,43910$ & $0,000^{* * *}$ \\
$\beta$ & \multicolumn{2}{c}{0,614274} \\
Korrigált $R^{2}$ & \multicolumn{3}{c}{$0,0026^{* * *}$} \\
\hline$E U-15$ & 3,60041 & 0,1138 \\
Konstans & $-0,519040$ & 0,118070 \\
$\beta$ & \multicolumn{3}{c}{$0,000^{* * *}$} \\
Korrigált $R^{2}$ & \multicolumn{3}{c}{$0,000^{* * *}$} \\
\hline Uj tagok & 14,0096 & 0,833848 \\
Konstans & $-4,51093$ & \multicolumn{2}{c}{0} \\
$\beta$ & \multicolumn{2}{c}{0,0} \\
\hline
\end{tabular}

*** 1 százalékos szinten, ${ }^{* *} 5$ százalékos szinten, ${ }^{*} 10$ százalékos szinten szignifikáns.

Forrás: saját szerkesztés.

\section{4. ábra}

Konvergenciaklubok az emisszióintenzitás esetében

Üvegháztartású gázok

egységnyi kibocsátására jutó

GDP éves átlagos változása (százalék)

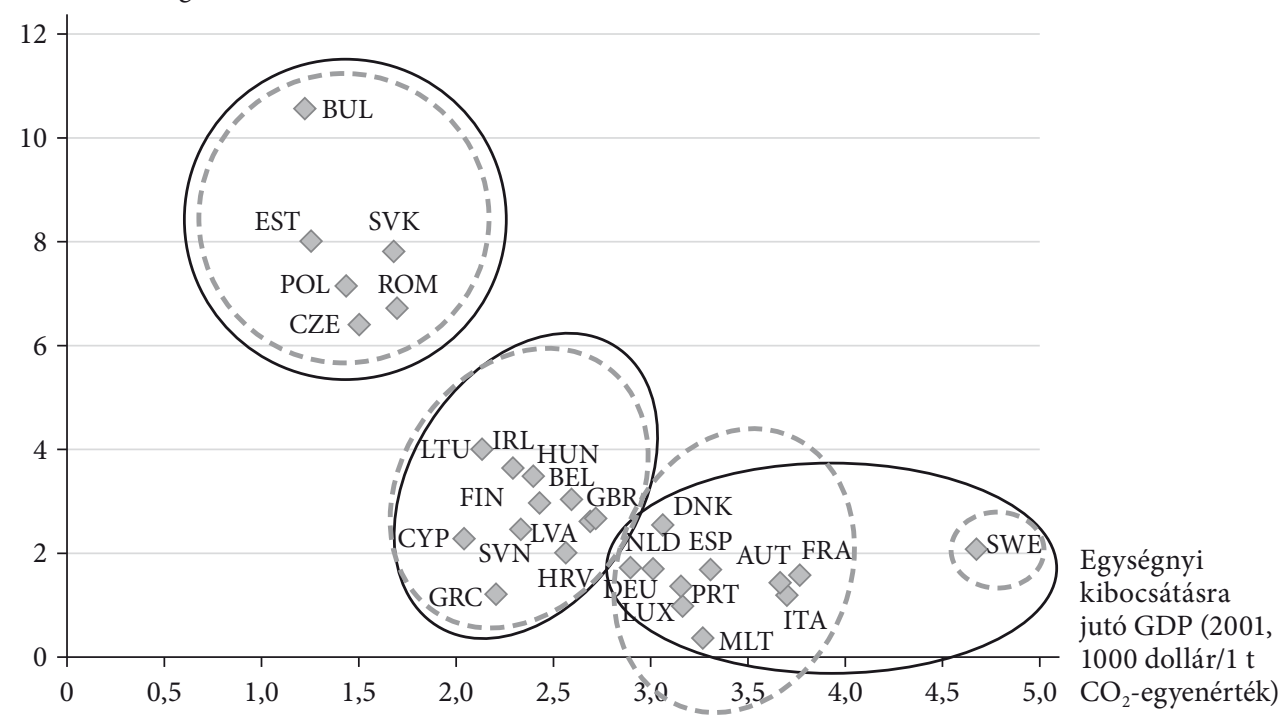

Megjegyzés: az országrövidítéseket lásd a 2. lábjegyzetben.

Forrás: saját szerkesztés. 
A 3. csoport tagjai: Belgium, Írország, Görögország, Finnország, Nagy-Britannia, Ciprus, Horvátország, Lettország, Litvánia, Magyarország és Szlovénia. Közepesnek mondható ezen országok kezdeti emisszióintenzitása, ami azonban jelentős fejlődéssel párosult. A legjobban teljesítők csoportjába (5. csoport) Lengyelország, Szlovákia, Észtország, Bulgária, Románia és Csehország tartozik: nagyon alacsony fejlettségi szintről indultak, de élen jártak a fejlődés tekintetében.

\section{Konvergenciaszámítások a megújuló energiaforrások részaránya esetében}

A vizsgált három indikátor közül a megújuló energiaforrások végső energiafelhasználáshoz viszonyított részaránya mutatja a legerősebben az összetartást, ebben az esetben a legnagyobb mértékű a különbségek csökkenése (5. ábra).

\section{5. ábra}

$\gamma$ és $\sigma$-konvergencia a megújuló energiaforrások esetében

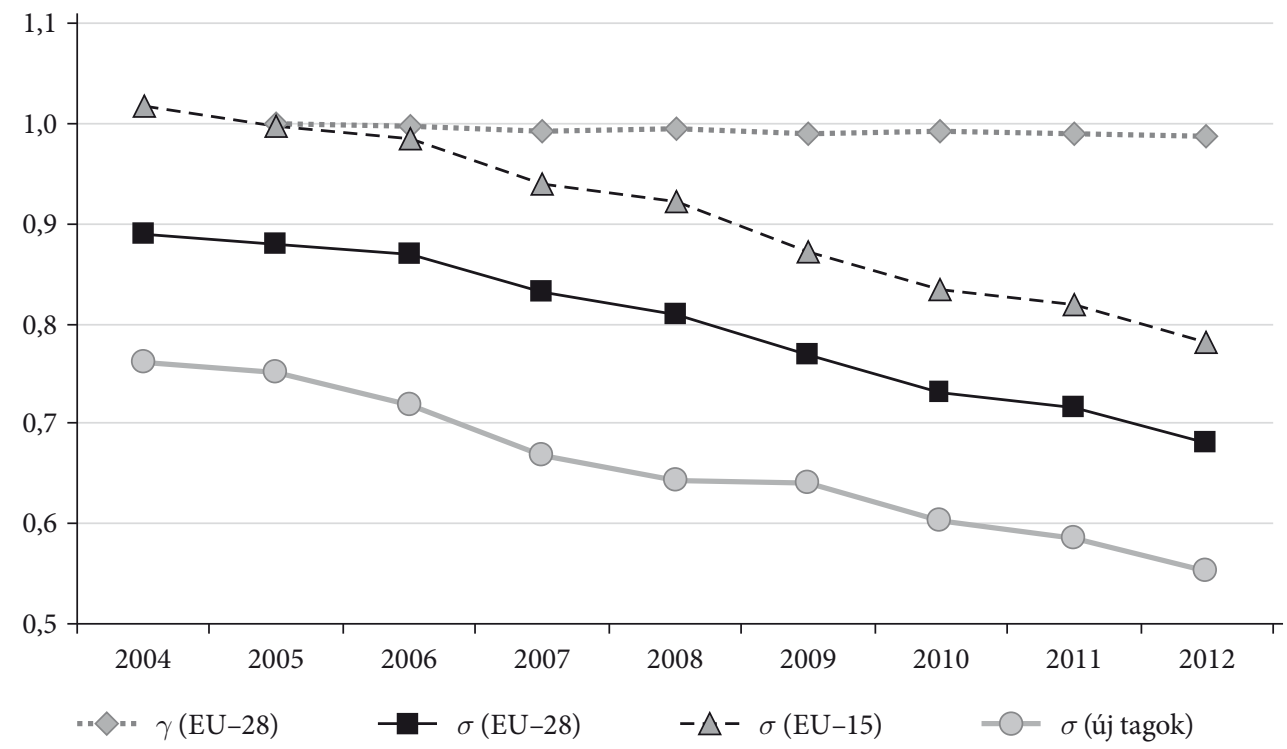

Forrás: saját szerkesztés.

Felmerül a kérdés, hogy a 2008-2009-es válság miért nem okozott - a másik két mutatóhoz hasonlóan - visszaesést, divergenciát a vizsgált országok között. Ennek egyrészt az a fó oka, hogy az egyszer már beépített megújulós kapacitások továbbra is használatban maradnak. Másrészt a mutató akkor is növekedhet, ha a végső energiafelhasználás csökken, miközben a megújuló energiaforrásokból származó energiafelhasználás stagnál.

A megújuló energiaforrások piacát - közvetetten, számos egyéb tényezőn keresztül jelentősen befolyásolja a kőolaj világpiaci árának alakulása, illetve annak hatása más instrumentumokra (például a földgáz, illetve az elektromos energia ára is nagymértékben 
függ tőle). 2008 nyarán a kőolaj világpiaci ára minden addig tapasztalt rekordot megdöntött (a WTI-olaj ára meghaladta a 146 dollárt). Ilyen piaci környezetben számos kőolaj- és földgáztüzelésủ erőmü leállítására sor került (például Tiszaújvárosban a Tisza-II. erőmüére is), amelyek már nem kellö hatékonysággal és drágán állítottak elő elektromos energiát. Ebben az időszakban ugyanakkor a megújuló energiaforrásokat érintő beruházások megtérülési ideje lerövidült, ami nemcsak az Európai Unióban hatott pozitívan az új kapacitások kiépítésére, hanem az egész világon: a beruházások értéke 2006-ról 2008-ra több mint 62 százalékkal nőtt az ENSZ Környezetvédelmi Programja (United Nations Environment Programme, UNEP) adatai szerint. A válság hatásaként nagymértékben csökkent a végső energiafelhasználás (különösen a közlekedésben és az ipari szektorban), ami gyorsította a régi, fosszilis energiaforrásokat használó, kiöregedett erőművek leállításának folyamatát. Eközben a megújuló energiaforrásokra épülő kapacitások üzemben maradtak, ami erősítette a tagállamok közötti konvergenciát.

Az energiaintenzitáshoz hasonlóan itt sem igazolható a $\gamma$-konvergencia jelenléte, tehát kijelenthetö, hogy a különbségek fennállnak az egyes tagállamok között, de a szóródásuk jelentősen csökkent 2004 és 2012 között.

A bázis- és tárgyidőszak közötti eltérések konvergenciáról tanúskodnak: a $\beta$ minden esetben negatív. Vagyis az alacsonyabb bázisidőszaki értékről induló országok tárgyidőszakra magasabb növekedési ütemet értek el, tehát az egyes országok azonos egyensúlyi állapothoz tartanak. A t-próba alapján látható, hogy a regressziós egyenlet minden tagja szignifikáns (mind a régi, mind az új, illetve az integráció egészében). A korrigált $R^{2}$ értéke közepesen erősnek mondható.

\section{6. táblázat}

$\beta$-konvergencia az Európai Unió 28 tagállamában a megújuló energiaforrások részaránya esetében

\begin{tabular}{|c|c|c|}
\hline & $\beta$ & $t$-érték \\
\hline \multicolumn{3}{|l|}{$E U-28$} \\
\hline Konstans & 9,90199 & $0,000^{* * *}$ \\
\hline$\beta$ & $-0,394818$ & $0,0010^{* * *}$ \\
\hline Korrigált $R^{2}$ & \multicolumn{2}{|c|}{0,330500} \\
\hline \multicolumn{3}{|l|}{$E U-15$} \\
\hline Konstans & 12,4832 & $0,0002^{* * *}$ \\
\hline$\beta$ & $-0,459776$ & $0,0110^{\star *}$ \\
\hline Korrigált $R^{2}$ & \multicolumn{2}{|c|}{0,357341} \\
\hline \multicolumn{3}{|l|}{$\overline{U j j}$ tagok } \\
\hline Konstans & 5,15710 & $0,000^{* * *}$ \\
\hline$\beta$ & $-0,200077$ & $0,0009^{* * *}$ \\
\hline Korrigált $R^{2}$ & \multicolumn{2}{|c|}{0,650723} \\
\hline
\end{tabular}

${ }^{* * *} 1$ százalékos szinten, ${ }^{* *} 5$ százalékos szinten, ${ }^{*} 10$ százalékos szinten szignifikáns.

Forrás: saját szerkesztés. 
A megújuló energiaforrások végső energiafelhasználáshoz viszonyított részaránya tekintetében kiemelkedően jól teljesített Málta és Nagy-Britannia, így ez a két ország önálló klubot képez (6. ábra). Ugyanakkor fontos megjegyezni, hogy ez a két ország indult a legalacsonyabb bázisértékről (Máltában 2004-ben 0,3 százalék volt a megújulók részaránya, Nagy-Britanniában 1,2 százalék), ahonnan relatíve könynyen lehet nagymértékü fejlődést produkálni.

\section{6. ábra}

Konvergenciaklubok a megújuló energiaforrások esetében

\section{Megújuló energiaforrások részarányának} éves átlagos változása (százalék)

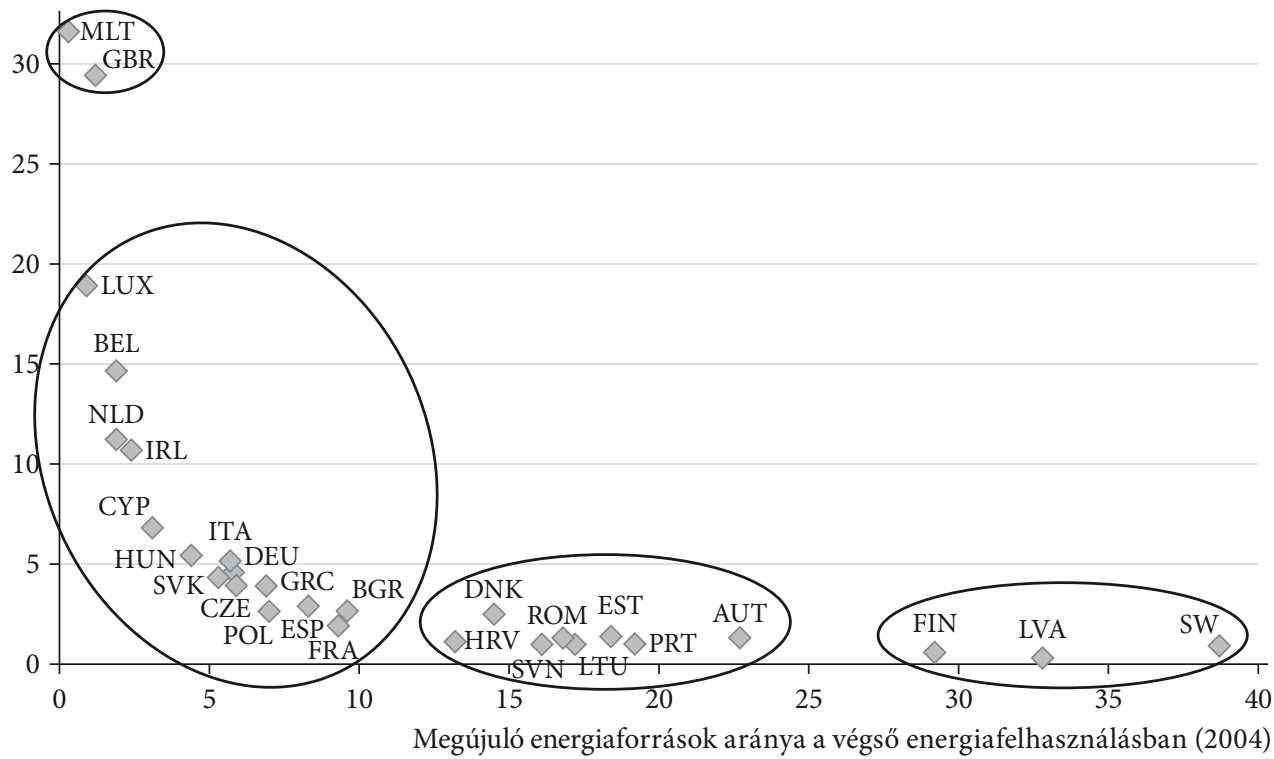

Megjegyzés: az országrövidítéseket lásd a 2. lábjegyzetben.

Forrás: saját szerkesztés.

A 2. klaszterhez Finnország, Lettország és Svédország tartozik. Hagyományosan energia- és környezettudatos országokról van szó, amelyek már 2004-ben is nagyon jelentős megújulóenergia-kapacitásokkal rendelkeztek. Bár az éves átlagos növekedési ütemük nem tűnik gyorsnak, de a magas kiindulási érték következtében még így is jelentős a kapacitásbővülés.

A 3. klasztert Dánia, Ausztria, Portugália, Észtország, Horvátország, Litvánia, Románia és Szlovénia alkotja. Ezen országok mindegyike 15-20 százalék körüli kiinduló étékkel rendelkezett 2004-ben, amely 5-10 százalékponttal emelkedett 2012-re.

A legnagyobb elemszámú 4. klaszterhez Belgium, Írország, Németország, Görögország, Spanyolország, Luxemburg, Hollandia, Franciaország, Olaszország, Bulgária, Csehország, Ciprus, Magyarország, Lengyelország és Szlovákia tartozik. Esetükben alacsony kiindulási érték párosul magasabb növekedési rátával, tehát a felzárkózási ütemük alapján közelednek a fejlettebbekhez. 


\section{Következtetések}

Az energiaintenzitásra, a megújuló energiaforrások részesedésének növelésére, illetve az üvegházhatású gázok kibocsátására vonatkozó, 20-20-20-as európai uniós célkitűzések jól kiegészítik egymást, ugyanakkor mind a döntéshozók, mind a gazdasági szereplők számára kiemelten fontos az előrehaladás nyomon követése. A megfelelő visszacsatolások révén javítható, illetve bővíthető az alkalmazott eszköztár, mérhető azok hatékonysága. Tanulmányunkban e három mutató esetében vizsgáltuk a $\sigma$-, $\gamma$ és az abszolút $\beta$-konvergencia jelenlétét 2001 és 2012 között az Európai Unió 28 tagállamában, továbbá konvergenciaklubokra is végeztünk számításokat.

A tagállamok közötti energetikai konvergencia vizsgálata során a következő, főbb megállapításokat tettük.

1. Az Európai Unióban mindhárom mutató esetében igazolható a $\sigma$-konvergencia. Ugyanakkor a $\gamma$-konvergencia - nagyon gyenge - jelenléte csak az emisszióra vonatkozó vizsgálattal igazolható, ami arra utal, hogy az egyes tagállamok közötti különbségek ugyan megmaradtak 2001 és 2012 között, de ezek mértéke jelentősen csökkent.

2. A $\sigma$-konvergenciára vonatkozó számítások a 2009-es évet fordulópontként jelzik az energia- és emisszióintenzitás esetében, ami így strukturális törést jelez. A konvergenciát felváltja a divergencia, ami azonban átmenetinek bizonyul (mintegy két évig tart).

3. A $\beta$-konvergencia mindhárom energetikai mutató esetében a gyengébben teljesítő országok felzárkózását mutatja az integráció egészét tekintve.

4. A $\sigma$-és $\beta$-konvergencia eredményei a régi és új tagországok közötti jelentős eltérésre hívják fel a figyelmet. Az energia- és emisszióintenzitásra végzett vizsgálatok alapján kijelenthető, hogy a 2004-ben, 2007-ben és 2013-ban csatlakozott országok közötti $\sigma$ - és $\beta$-konvergencia jóval erösebb, mint az integráció egészére számított értékek. Ugyanakkor a régi tagállamokra számított $\beta$ érték nem szignifikáns ezekben az esetekben, a $\sigma$-konvergencia pedig az egyenlötlenségek állandósulását mutatja. Tehát azok az országok, amelyeket kezdetben rosszabb energiahatékonyság-, illetve emiszsziós adatok jellemeztek (ezek lesznek az új tagállamok), gyorsabban fejlödnek, mint azok a gazdaságok, amelyek eleve jobban teljesítettek (régi tagok).

5. A vizsgálatba bevont három indikátor közül a megújuló energiaforrások/végső energiafelhasználás mutatót tekintve a legerősebb a nemzetek közötti összetartás a $\sigma$ - és $\beta$-konvergenciára végzett számítások szerint.

6. A konvergenciaklubok számítása során kialakult csoportok - minimális keveredéssel - szintén a régi és új tagállamok mentén rendeződnek.

Fontosnak tartjuk megjegyezni, hogy a 2001-2012 között eltelt, 12 éves időtartamra végzett számítások alapján nem lehet a tagállamok közötti energetikai konvergencia hosszú távú alakulására következtetni. Ehhez sokkal több évet felölelő adatbázisra, illetve a feltételes konvergencia vizsgálatára lenne szükség, amelyet kutatásunk következő részében kívánunk elvégezni. Ugyanakkor a meglévő elemzések is betekintést nyújtanak a jelenleg is zajló folyamatokba, hozzájárulnak a 20-20-20-as célok teljesülésének ellenőrzéséhez, visszacsatolások készítéséhez. 


\section{Hivatkozások}

AdHIKARI D.-Chen Y. [2014]: Energy productivity convergence in Asian countries: a spatial panel data approach. International Journal of Economics and Finance, Vol. 6. No. 7. 94-107. o. http://dx.doi.org/10.5539/ijef.v6n7p94.

BARro, R. J. [1991]: Economic growth in a cross-section of countries. The Quarterly Journal of Economics, Vol. 106. No. 2. 407-443. o. http://dx.doi.org/10.2307/2937943.

Barro, R. J.-Sala-I-Martin, X. [1992]: Convergence. Journal of Political Economy, Vol. 100. No. 2. 223-251. o. http://dx.doi.org/10.1086/261816.

Benedek József-Veress Nóra-Csilla [2013]: Economic Disparities and Changes in the Convergence of the Romanian NUTS 2 and NUTS 3 Regions. Romanian Review of Regional Studies, Vol. 9. No. 1. 85-90. o.

Boyle G. E.-McCarthy T. G. [1997]: A simple measure of beta-convergence. Oxford Bulletinn of Economics and Statistics, Vol. 59. No. 2. 257-264. o. http://dx.doi.org/10.1111/14680084.00063.

Boyle G. E.-McCarthy T. G. [1999]: A simple measure of convergence in per capita GDP. A note on some further international evidence. Applied Economics Letters, Vol. 6. No. 6. http://dx.doi.org/10.1080/135048599353041.

Burnett, J. W. [2013]: Club convergence and clustering of U.S. Energy-related $\mathrm{CO}_{2}$ emissions AAEA \& CAES Joint Annual Meeting, https://ideas.repec.org/p/ags/aaea13/149578.html.

Camarero, M.-Picazo-Tadeo, A. J.-Tamarit, C. [2013]: Are the determinants of $\mathrm{CO}_{2}$ emissions converging among OECD countries? Economics Letter, 118. 159-162. o. http://dx.doi. org/10.1016/j.econlet.2012.10.009.

Csereklyei, Zsuzsanna-Mar Rubio Varas, M. D.-Stern, D. I. [2014]: Energy and economic growth: the stylized facts. CCEP Working Paper, 1417 https://ccep.crawford.anu.edu.au/sites/ default/files/publication/ccep_crawford_anu_edu_au/2014-12/ccep1417.pdf.

EB [2005]: Zöld könyv az energiahatékonyságról, avagy többet kevesebbel. COM (2005) 0265. végleges, Európai Közösségek Bizottsága, Brüsszel, június 22. http://eur- http://eur-lex. europa.eu/legal-content/HU/TXT/PDF/?uri=CELEX:52005DC0265\&from=HU.

EB [2006a]: Zöld könyv. Európai stratégia az energiaellátás fenntarthatóságáért, versenyképességéért és biztonságáért SEC (2006) 317. végleges. Európai Közösségek Bizottsága, Brüsszel, augusztus 3. http://eur-lex.europa.eu/legal-content/HU/TXT/?uri=CELEX: 52006DC0105.

EB [2006b]: Energiahatékonysági cselekvési terv: a lehetőségek kihasználása. COM (2006) 545. végleges. Európai Közösségek Bizottsága, Brüsszel, december 19. http://eur-lex.europa.eu/ legal-content/HU/ALL/?uri=CELEX:52006DC0545.

EB [2007a]: A Bizottság zöld könyve a Tanácsnak, az Európai Parlamentnek, az Európai Gazdasági és Szociális Bizottságnak és a Régiók Bizottságának - Alkalmazkodás az éghajlatváltozáshoz Európában - Az uniós fellépés lehetőségei COM (2007) 354. Európai Közösségek Bizottsága, Brüsszel, június 29. http://eur-lex.europa.eu/legal-content/HU/ TXT/?uri=CELEX:52007DC0354.

EB [2007b]: Európai energiapolitika COM/2007/0001 végleges, Európai Közösségek Bizottsága, Brüsszel, január 10. http://eur-lex.europa.eu/legal-content/HU/ALL/?uri=CELEX: 52007 DC0001.

EB [2007c]: Megújulóenergia-útiterv. Megújuló energiák a XXI. században: egy fenntarthatóbb jövő építése COM (2006) 848 végleges. A Bizottság közleménye, 2007. január 10. http:// europa.eu/legislation_summaries/energy/renewable_energy/127065_hu.htm. 
EB [2008]: Az energiapolitika második stratégiai felülvizsgálata. Az Európai Unió cselekvési terve az energiaellátás biztonsága és az energiapolitikai szolidaritás terén COM (2008) 781 végleges. Európai Közösségek Bizottsága Brüsszel, november 13. http://eur-lex.europa.eu/ legal-content/HU/ALL/?uri=CELEX:52008DC0781.

EB [2009]: Fehér Könyv. Az éghajlatváltozáshoz való alkalmazkodás. Egy európai fellépési keret felé COM (2009) 147 végleges Európai Közösségek Bizottsága, 147 végleges Brüszszel, április 8. http://eur-lex.europa.eu/LexUriServ/LexUriServ.do?uri=COM:2009:0147: FIN:HU:PDF.

EB [2010]: Energia 2020. A versenyképes, fenntartható és biztonságos energiaellátás és -felhasználás stratégiája. COM/2010/0639 Európai Bizottság, Brüsszel, január 14. http://eur-lex.europa. eu/LexUriServ/LexUriServ.do?uri=CELEX:52010DC0639R\%2802\%29:HU:HTML.

EB [2011a]: 2011. évi energiahatékonysági terv. COM (2011) 109 végleges. Európai Bizottság Brüsszel, március 8. http://eur-lex.europa.eu/legal-content/HU/ALL/?uri=CELEX: 52011DC0109.

EB [2011b]: Az alacsony szén-dioxid-kibocsátású, versenyképes gazdaság 2050-ig történő megvalósításának ütemterve COM (2011) 112 végleges. Európai Bizottság, Brüsszel, március 8. http:// eur-lex.europa.eu/LexUriServ/ LexUriServ.do?uri=COM:2011:0112:FIN:HU:PDF.

EB [2013]: Zöld könyv az éghajlat- és energiapolitika 2030-ra szóló keretéről COM (2013) 169. Európai Bizottság, Brüsszel, Brüsszel, március 27. http://eur-lex.europa.eu/LexUriServ/ LexUriServ.do?uri=COM:2013:0169:FIN:HU:PDF.

EB [2014]: Éghajlat- és energiapolitikai keret a 2020-2030-as időszakra COM (2014) 15 végső. Európai Bizottság, Brüsszel, január 22. http://www.ipex.eu/IPEXL-WEB/dossier/document/ COM20140015.do.

EC [1997]: Communication from the Commission Energy for the future: renweable sources of energy COM(97)599 final. White Paper for a Community Strategy and Action Plan COM(97)599 final, European Commission, Brüsszel, november 26. http://europa.eu/ documents/comm/white_papers/pdf/com97_599_en.pdf.

ET [2014]: A 2030-ig tartó időszakra vonatkozó éghajlat- és energiapolitikai keret. Európai Tanács, Brüsszel, október 23. http://www.consilium.europa.eu/uedocs/cms_data/docs/ pressdata/HU/ec/145379.pdf.

Európai Parlament és Tanács [2006]: Az Európai Parlament és Tanács 2006/32/EK irányelve az energia-végfelhasználás hatékonyságáról és az energetikai szolgáltatásokról, valamint a 93/76/EGK tanácsi irányelv hatályon kívül helyezéséről. HL, L 114/64 április 27. http://eurlex.europa.eu/legal-content/HU/TXT/PDF/?uri=CELEX:32006L0032\&from=HU.

EzCURRA, R. [2007]: Distribution dynamics of energy intensities. A cross-country analysis. Energy Policy, Vol. 35. No. 10. 5254-5259. o. http://dx.doi.org/10.1016/j.enpol.2007.05.006.

GÁspár Attila [2010]: Klub-konvergencia mérése a világ országaiban. Kézirat, http://media. coauthors.net/konferencia/conferences/3/MKE.pdf.

Најко, V. [2012]: Changes in the energy consumption in EU-27 countries. Review of Economics Perspectives, Vol. 12. No. 1. 3-21. o. http://dx.doi.org/10.2478/v10135-012-0001-y.

KocZISZKY GYÖRGY [2010]: Opportunities and Limits of Economic Convergence for Hungary. European Integration Studies, Miskolc, Vol. 8. No. 1. 47-60. o.

LIDDLE, B. [2009]: Electricity intensity convergence in IEA/OECD countries: aggregate and sectoral analysis. Energy Policy, Vol. 37. No. 2. 1470-1478. o. http://dx.doi.org/10.1016/j. enpol.2008.12.006.

Liddle, B. [2012]: OECD Energy intensity. Measures, trends and convergence. Energy Efficiency, Vol. 5. No. 4. 583-597. o. http://dx.doi.org/10.1007/s12053-012-9148-8. 
Major Klára [2001]: A nemzetközi jövedelemegyenlőtlenség dinamikája. PhD-értekezés, Budapesti Corvinus Egyetem, Közgazdaságtani Doktori Iskola, http://phd.lib.unicorvinus.hu/271/1/major_klara.pdf.

Markandya, A.-Pedroso-Galinato, S.-Streimikiene, D. [2006]: Energy intensity in transition economies. Is there convergence towards the EU average? Energy Economics, Vol. 28. No. 1.121-145. o. http://dx.doi.org/10.1016/j.eneco.2005.10.005.

Meng, M.-PAyne, J. E.-LeE, J. [2013]: Convergence in per capita energy use among OECD countries. Energy Economics, 36. 536-545. o. http://dx.doi.org/10.1016/j.eneco. 2012.11.002.

Mielnik, O.-Goldemberg, J. [2000]: Converging to a common pattern of energy use in developing and industrialized countries. Energy Policy, Vol. 28. No. 8. 503-508. o. http:// dx.doi.org/10.1016/s0301-4215(00)00015-x.

Mohammadi, H.-RAm, R. [2012]: Cross-country convergence in energy andelectricity consumption, 1971-2007. Energy Economics, Vol. 34. No. 6. 1882-1887. o. http://dx.doi. org/10.1016/j.eneco.2012.08.001.

Moutinho, V.-Robaina-Alves, M.-Mota, J. [2014]: Carbon dioxide emissions intensity of Portuguese industry and energy sectors: A convergence analysis and econometric approach Renewable and Sustainable. Energy Reviews, Vol. 40. 438-449. o. http://dx.doi. org/10.1016/j.rser.2014.07.169.

Mulder, P.-Groot, H. L. F. [2012]: Structural change and convergence of energy intensity across OECD countries, 1970-2005. Energy Economics, Vol. 34. No. 6. 910-1921. o. http:// dx.doi.org/10.1016/j.eneco.2012.07.023.

Nemes Nagy József [2005]: Regionális elemzési módszerek. Regionális Tudományi Tanulmányok, ELTE Regionális Földrajzi Tanszék, MTA-ELTE Regionális Tudományi Kutatócsoport, Budapest.

Oblath GÁBOR-SzÖRfi BÉLA [2008]: Makrogazdasági konvergencia az EU új tagországaiban. Megjelent: Kolosi Tamás-Tóth István György (szerk.): Társadalmi riport, 2008. 204-225. o. Tárki, Budapest, http://www.tarsadalomkutatas.hu/kkk.php?TPUBL-A-814/ publikaciok/tpubl_a_814.pdf.

RoAdmap [2009]: Roadmap 2050. European Climate Foundation, http://www.roadmap 2050.eu.

Quah, D. T. [1996]: Empirics for Economic Growth and Convergence. European Economic Review, Vol. 40. No. 6. 1353-1375. o. http://dx.doi.org/10.1016/0014-2921(95)00051-8.

SAjtos, L.-Mitev, A. [2007]: SPSS kutatási és adatelemzési kézikönyv. Alinea Kiadó, Budapest.

STERN, D. I. [2011]: The role of energy in economic growth. Annals of the New York Academy of Sciences, Vol. 1219. Ecological Economics Reviews, 26-51. o. http://dx.doi.org/10.1111/ j.1749-6632.2010.05921.x.

SzENDI, D. [2013]: The convergence process and the effects of the economic crisis in CentralEastern Europe. Romanian Review of Regional Studies, Vol. 9. No. 1.

Szlávik János [2013]: Fenntartható gazdálkodás. CompLex Kiadó, Budapest.

Tóth Géza-Nagy Zoltán [2014]: Same or Different Development Paths? A Comparative Study of the Large Cities and Regions in Hungary. Regional Statistics, Vol. 4. No. 1. 100119. o. http://dx.doi.org/10.15196/RS04107.

UNEP [2015]: Global Trends in Renewable Energy Investment 2015. http://fs-unep-centre. org/publications/global-trends-renewable-energy-investment-2015.

VILÁGBANK [2015]: World Development Indicators adatbázis, www.worldbank.org. 


\section{Függelék}

F1. táblázat

A vizsgált adatok alakulása az Európai Unióban

\begin{tabular}{|c|c|c|c|c|c|c|c|}
\hline & \multicolumn{2}{|c|}{$\begin{array}{l}\text { Energiaintenzitás } \\
\text { (koe/ezer euró) }\end{array}$} & \multicolumn{2}{|c|}{$\begin{array}{l}\text { Üvegházhatású } \\
\text { gázok kibocsátása } \\
(1990=100)\end{array}$} & \multicolumn{3}{|c|}{$\begin{array}{l}\text { Megújuló energiaforrások } \\
\text { részaránya a végső } \\
\text { energiafelhasználásban }\end{array}$} \\
\hline & 2001 & 2012 & 2001 & 2012 & 2004 & 2012 & Célérték \\
\hline Ausztria & 133,9 & 123,9 & 108,81 & 104,02 & 22,7 & 32,1 & 34 \\
\hline Belgium & 206,8 & 172,2 & 102,29 & 82,56 & 1,9 & 6,8 & 13 \\
\hline Bulgária & 1040,1 & 669,9 & 57,31 & 56,02 & 9,6 & 16,3 & 16 \\
\hline Ciprus & 201,0 & 167,0 & 144,72 & 147,72 & 3,1 & 6,8 & 13 \\
\hline Csehország & 477,8 & 355,4 & 74,73 & 67,32 & 5,9 & 11,2 & 13 \\
\hline Dánia & 103,3 & 87,2 & 102,87 & 76,93 & 14,5 & 26,0 & 30 \\
\hline Észtország & 616,8 & 478,7 & 43,20 & 47,40 & 18,4 & 25,8 & 25 \\
\hline Finnország & 234,8 & 204,0 & 105,82 & 88,13 & 29,2 & 34,3 & 38 \\
\hline Franciaország & 165,1 & 142,9 & 101,26 & 89,46 & 9,3 & 13,4 & 23 \\
\hline Görögország & 176,4 & 165,7 & 120,91 & 105,71 & 6,9 & 13,8 & 18 \\
\hline Hollandia & 158,5 & 149,4 & 103,54 & 93,26 & 1,9 & 4,5 & 14 \\
\hline Horvátország & 265,4 & 225,6 & 86,53 & 82,65 & 13,2 & 16,8 & 20 \\
\hline Írország & 112,5 & 82,8 & 128,57 & 107,04 & 2,4 & 7,2 & 16 \\
\hline Lengyelország & 423,0 & 298,7 & 84,30 & 85,85 & 7,0 & 11,0 & 15 \\
\hline Lettország & 442,7 & 328,6 & 40,50 & 42,92 & 32,8 & 35,8 & 40 \\
\hline Litvánia & 527,8 & 291,6 & 42,36 & 44,41 & 17,2 & 21,7 & 23 \\
\hline Luxemburg & 147,4 & 133,8 & 85,02 & 97,48 & 0,9 & 3,1 & 11 \\
\hline Magyarország & 344,3 & 268,7 & 80,54 & 63,70 & 4,4 & 9,6 & 14,65 \\
\hline Málta & 190,6 & 147,4 & 134,76 & 156,90 & 0,3 & 2,7 & 10 \\
\hline Nagy-Britannia & 140,5 & 105,1 & 91,70 & 77,50 & 1,2 & 4,2 & 15 \\
\hline Németország & 160,7 & 129,2 & 85,26 & 76,55 & 5,8 & 12,4 & 18 \\
\hline Olaszország & 125,6 & 117,3 & 108,02 & 89,72 & 5,7 & 13,5 & 17 \\
\hline Portugália & 168,9 & 146,5 & 137,88 & 114,87 & 19,2 & 24,6 & 31 \\
\hline Románia & 579,5 & 378,8 & 56,11 & 47,96 & 16,8 & 22,9 & 24 \\
\hline Spanyolország & 158,0 & 136,4 & 133,79 & 122,48 & 8,3 & 14,3 & 20 \\
\hline Svédország & 193,8 & 148,2 & 96,19 & 80,73 & 38,7 & 51,0 & 49 \\
\hline Szlovákia & 599,5 & 329,3 & 70,30 & 58,40 & 5,3 & 10,4 & 14 \\
\hline Szlovénia & 273,6 & 227,7 & 107,59 & 102,62 & 16,1 & 20,2 & 25 \\
\hline
\end{tabular}

Forrás: az Eurostat adatbázisa alapján saját szerkesztés. 